\title{
The Engineer and the Nation
}

$\mathrm{I}^{\mathrm{N}}$ his presidential address to Section G (Engineering) of the British Association, delivered on September 10, Prof. William Cramp took as his subject "The Engineer and the Nation" and, in the course of a very human and entertaining sketch, found opportunity to define the special functions of the engineer, to claim for him an appropriate degree of authority and independence in his own domain and to discourage the prevalent repression of technical knowledge and skill in the interest of commercial advantage or in favour of false standards of economy. The activities of the engineer, he holds, are closely linked with the national life and its progress and, to a very large extent, take the form of applying and bringing to the service of the community the knowledge previously gained by the physicist, the chemist and the metallurgist. $\mathrm{He}$ is not, however, detached from the work of fundamental research, for his training is in close touch with it and enables him frequently to bring to a conclusion the unfinished work of his collaborators in the field of pure science. As an instance of this, Prof. Cramp ascribed to the engineer the evolution of the Cooper-Hewitt are rectifier from its humble beginnings to its present outstanding position as the most important converter in heavy electrical engineering.

The fundamental differences between those engaged in the pursuit of pure science and the engineer are to be found in the conditions under which they must work and in the ends toward which they strive. For the investigation and study of natural phenomena and their laws, the scientific worker requires quiet detachment and, for him, the main purposes are to know what is unknown, to observe behaviour, to determine natural laws, to construct a framework of principles fitting the collected observations. The engineer, on the other hand, must keep in close touch with the life and interests of the community, and the major part of his work is done under the conditions of intense and orderly bustle associated with construction. His aim is to apply knowledge, to link it with the experience of the ages, to utilize and to conserve the energy that is available for the increase of the amenities of life. In this way, engineering has become the greatest instrument of eivilization the world has known; at least threefourths of its work consists in making, maintaining and developing communications.

While it may not be possible to accede to Prof. Cramp's claim that, left undisturbed by politicians, scaremongers and patriots, the engineer would render war impossible, the thoughtful will be able to appreciate from the context of examples and suggestions the underlying truth and moral of his case. But whether in peace or in war, the products of the knowledge and skill of the engineer as a pioneer are vitally important, so to the nations and to the world at large his activities and the ends to which he directs them are matters of supreme concern. Thus it is that the man, the engineer, is at all times closely associated with human relationships, and his opportunities for development or loss of character are great; his chances of salva. tion and his risks of damnation are increased, for character does not mature in cloisters, and exposure is necessary for the proof of it.

Finding the engineer so privileged in the nature of the services he can render to the community, Prof. Cramp then asks to what extent do his fellow men recognize his real and potential importance, and how far does he abuse his position or allow himself to be made the tool of less scrupulous men. Although the period and extent of his training correspond to those of the doctor and lawyer, the engineer has no similar status nationally recognized, nor does he on the average receive the same rewards. Men responsible for the design of high-speed turbo-generators or for other work transcending that of the doctor in respect of the safety, not merely of individuals but of masses, may never receive more than $£ 750$ per annum. On the other side of the account, instances are given of unprofessional conduct; while it is out of place here to recapitulate details of the commercial practices of individuals, firms, and associations to which Prof. Cramp referred, it is to be hoped that his plea for a higher standard of integrity may have good effect and may assist in promoting the reforms he suggested.

In the forefront of these reforms Prof. Cramp places the need for a body with statutory powers to define the qualifications and status of those who may use the titles at present freely adopted, to prevent unqualified persons from jeopardizing life and also to check unprofessional conduct. Expressly it is stated that such a measure of immunity as has been achieved by the legal and medical professions is not desired. An urgent reform also is the proper representation of science on governing bodies in industry and in technical departments in the State and municipalities; and here it was suggested that the British Associations should take steps and also appoint a committee. Some means by which the engineer shall not be over-ruled in technical matters by the commercial man, drastic 
alteration of the patents procedure in the law courts and a suggestion for the revision of the constitution of the councils of the trade associations by making them representative of makers, contractors and buyers are also urged as much needed reforms.

Finally, there is the question of the general professional code. Backsliding, Prof. Cramp finds, can only be corrected by a higher training of character and, in his concluding words, "The remedy lies in the hands of parents and those who control educational institutions : it is urgent and of national importance. I commend its consideration to the Board of Education, the Committee of Vice-Chancellors, and to the members of Section L. British engineers have, in the past, earned a great reputation for reliability and straight dealing. This is a national asset of real value, which can only be maintained if, as in our national games, we learn to place integrity before self-interest".

\section{The Place of Science in General History}

$\mathrm{A}$ MARKED change has taken place in recent years in the attitude of the 'general historian' to natural science. Fifty, or even forty years ago, it was possible for S. R. Gardiner to write a history of England covering the life of Newton, and to allude to Newton only as Master of the Mint. To-day, in every book of similar scope and size, something would be said about the achievements of science in the seventeenth century, as well, probably, as something about the connexion of science with the industrial developments of the eighteenth and nineteenth. This is all to the good, and in the same direction should be noted the recent great interest in 'pre-history'. The last will probably prove in the end the decisive factor in changing the focus from which we regard the past, or rather-to use a more appropriate metaphor-the centre of gravity on which the past and present repose. As this is the capital point in the discussion, it will be best to make it clear at starting.

The older, and still prevalent, view regarded the agents and the machinery by which the government of nations is carried on as the dominant factor in human affairs. Hence, in practically all historical works of a general kind, the writer spent his chief, often his whole, pains in describing this type of action and the characters of those who did it. For this reason all of us have some sort of picture in the mind of the most eminent and interesting kings, emperors, soldiers and statesmen. They serve, of course, a very useful function as landmarks in the course of time, as points-de-repère round which we may collect the other fragments of knowledge which we possess. But the newer and truer point of view carries the matter a good deal further back. The really determinant factors in human life in the long run are more profound, more obscure and, above all, more purely mental. The revelations of pre-history make this clear. We find, probe as far as we may, that, millenniums ago, the mind of early man was at work making inventions and observations which laid the foundation of all the civilization which has followed. When we grasp this, we must be led on to see that the mental process is a continuous one and that the abstract-thinking mind becomes more, and not less, dominant as history proceeds.

The question, therefore, which every honest person must put to himself is this : Do we really desire to know the true connexions of things in the past, the authentic structure of the society of which we are a part, or do we prefer the superficially more exciting incidents which the novelist historians are always ready to turn out? Is it the 'private life of Henry VIII' and the mistresses of Charles II, or the scientific revolution which took place between those monarchs, which really interests us the most? All are a part of history, and all historians and readers of history must select.

One must not be understood to belittle the importance of the governmental side of history, or to be attempting to identify it with the personal foibles of its prominent actors. But it is necessary in the interest of truth to assert that hitherto there has been a vast miscarriage of interest and attention in this matter, which is a vital one for the intellectual integrity of the race.

How may the correction be best carried out, without revolution, and without lessening the total amount of interest which the thinking public is inclined to give to history?

In the first place, the change must take place gradually and by the mental conversion, both of those who write and those who read history. This follows from the very thesis that we are maintaining. Mind rules the world, and this is a case of men's minds awakening to the real nature of the process. Evidence is abundant that most of the competent minds which have turned to the subject now realize, more or less dimly, the nature of the truth, and the truth is spreading. Lord 